\title{
Helminths of the Eastern Tree Frog, Hyla orientalis, Bedriaga, 1890 (Anura: Hylidae), collected from Denizli Province, Inner-West Anatolia Region, Turkey
}

\author{
S. DÜŞEN*, H. YAKA \\ Pamukkale University, Faculty of Arts and Sciences, Department of Biology, Kinikli Campus, Kinikli 20017 Denizli, \\ Turkey, *E-mail: sdusen@pau.edu.tr,serdar2290@yahoo.com
}

\begin{abstract}
Summary
In this investigation, Hyla orientalis (eastern tree frog) was collected in different localities from Denizli province (Inner-west Anatolia Region - the eastern part of Aegean Region) Turkey, between 2008 and 2011 and examined for the first time for helminths. Also, this study contains first detailed SEM imaging attempt of the some amphibian helminths from Turkey. Of 17 Hyla orientalis 8 (47.05\%) were infected with one or more helminths. Hyla orientalis harbored one species of Monogenea 1 (Polystoma skrjabini), one species of Digenea (Pleurogenoides medians), three species of nematoda (Oswaldocruzia filiformis, Cosmocerca ornata and Abbreviata sp.), and one species of Acanthocephala (Acanthocephalus ranae). All helminths recorded first time for Hyla orientalis.
\end{abstract}

Keywords: Acantocephala; Denizli; Digenea; Helminth; Hyla orientalis; Hylidae; Monogenea; Nematoda; SEM; Turkey

\section{Introduction}

Previously, the eastern tree frog $H$. orientalis was not distinguished from $H$. arborea, this species is formerly known as H. arborea (Linnaeus, 1758) in, Turkey and vicinity; Stöck et al. (2008) stated that south-eastern European and western Anatolian $H$. arborea populations should be considered a separate species. So, they split $H$. arborea into three species based on molecular data, and resurrected the name $H$. orientalis Bedriaga, 1890 for the eastern populations (e.g. Bulgaria, Ukraine, Turkey and Iran) (Gvoždík, 2010; Gvoždík et al., 2010; Gül et al., 2012).

The eastern tree frog $H$. orientalis is a small arboreal species. It is nocturnal in habit and shelters under leaves in the daytime; it goes to water only in the breeding season, preferring clean, deep, heavily-vegetated water. In Turkey, this species is known in west, north and south-western Anatolia (Baran et al., 2012). To our knowledge, the first helminthological study on a Hylid member (H. arborea) was published by Düşen and Öz (2004) in Turkey. They recorded six nematode species from southwestern Turkey. Yildirımhan et al (2006a) is reported three helminths in Hyla arborea from north-western Turkey.

So far, there has been no published study on helminths of eastern tree frog (H. orientalis) from Denizli province, and its vicinity (Inner-west Anatolia Region - the eastern part of Aegean Region) in Turkey. This is the first helminthological investigation which has been done in this province.

\section{Materials and methods}

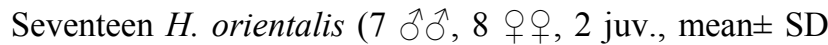
snout-vent length $(\mathrm{SVL})=47.56 \pm 7.13 \mathrm{~mm}$, a range 26.79 - $52.16 \mathrm{~mm})$, were collected between 2008 - 2011 in Denizli province $\left(38^{\circ} 29^{\prime}-38^{\circ} 52^{\prime} \mathrm{N}-28^{\circ} 38^{\prime}-30^{\circ} 05^{\prime} \mathrm{E}\right)$ and vicinity (Fig. 1), within $24 \mathrm{hr}$, toads were overdosed with ether.

The body cavities were opened by a longitudinal ventral incision, the alimentary canal was excised and separated into stomach, small intestine, large intestine and rectum. The contents of each and organ were each mixed with $0.5 \%$ saline solution and were poured into petri dishes for

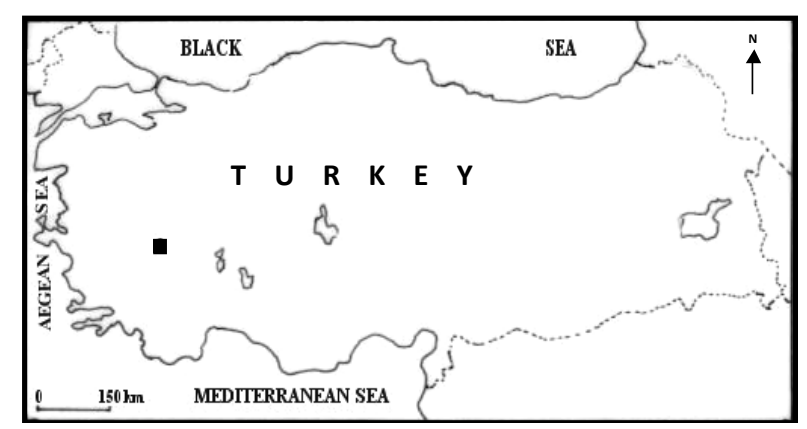

Fig. 1. The collecting locality of $H$. orientalis from inner-west Anatolia Region in Turkey 
examination under a stereomicroscope. The lungs, liver, gall bladder, kidneys and urinary bladder were also searched for helminths. Trematode samples were immobilized by heat, fixed, and stored in $70 \%$ ethanol. Nematodes were straightened by heat, fixed, and stored in $70 \%$ ethanol with $5 \%$ glycerol. Acanthocephalans were relaxed in saline and heat-fixed under slight coverslip pressure in warm alcohol-formalin-acetic acid. Monogenean, digenean and acanthocephalan samples were stained with acetocarmine, dehydrated, cleared in cedar oil, and mounted in Entellan $^{\circledR}$; nematodes were cleared in glycerol and examined. Intesities are presented as mean values followed by the range. Voucher host specimens and parasite specimens were deposited in Pamukkale University, Faculty of Sciences and Arts, Department of Biology, Denizli, Turkey, under the accession number (PAU-HELM-5-10/2013).

For SEM (Scanning Electron Microscope), samples of some helminths had been stored in $70 \%$ ethanol were processed following standard methods, (Schatten \& James, 2008) that included critical point drying in porous capsules (pore diameter is $100 \mu \mathrm{m}$ ) and mounted on SEM sample mounts using conductive double sided carbon tape. Helminth samples were then gold coated for 3 minutes using a sputter coater establishing an approximate thickness of 20nm. Samples were then placed in a Zeiss-Leo 14320 under low vacuum conditions. Permanent images were obtained with a digital camera at various magnifications.

\section{Results and discussion}

\section{Hyla orientalis, Bedriaga, 1890}

Seventeen specimens ( $7 \hat{\partial}, 8$ 우, 2 juv.) were collected between 2008 - 2011 years from Denizli province, Turkey.
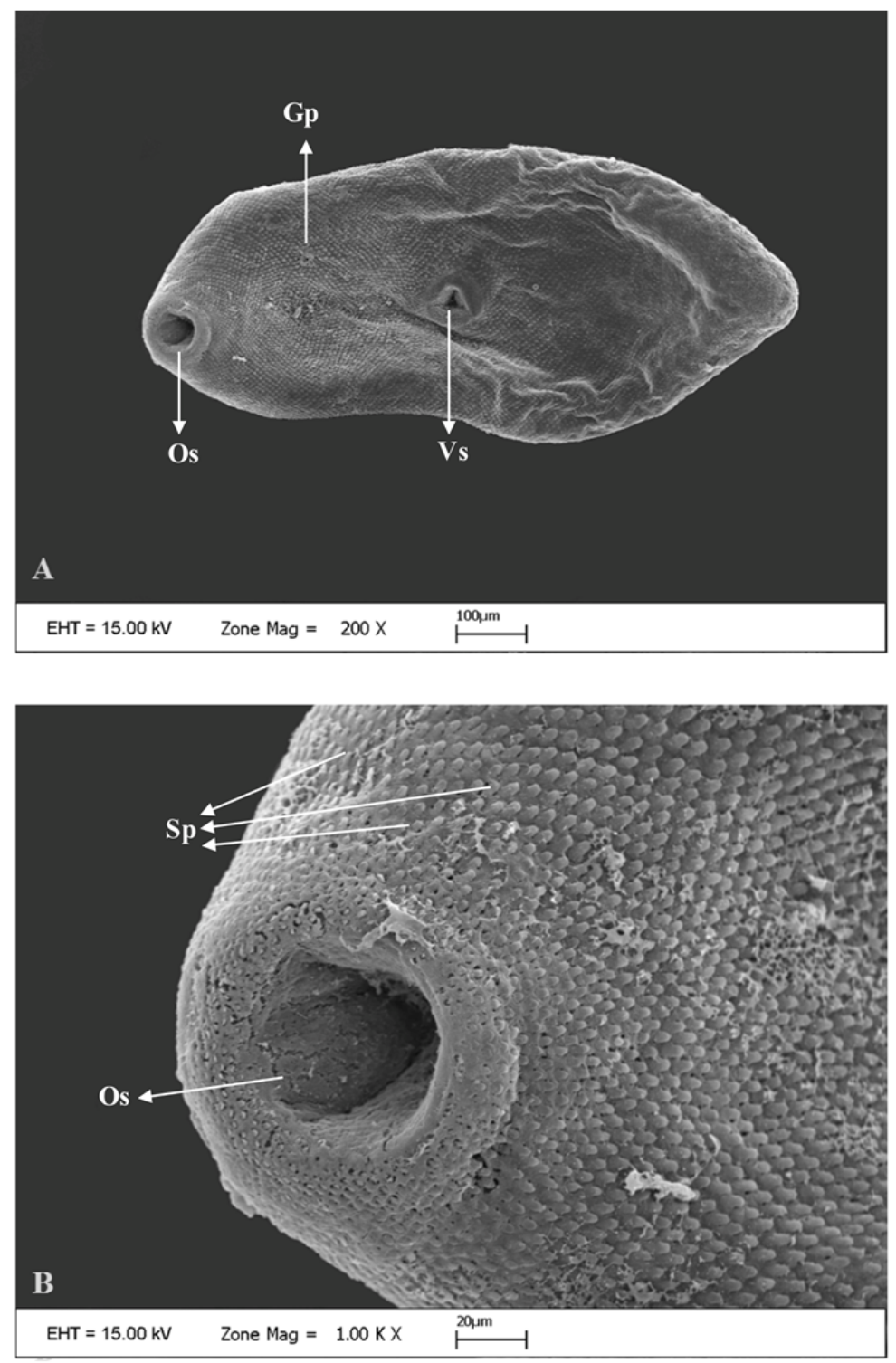

Fig. 2. SEM of specimens of Pleurogenoides medians from $H$. orientalis.

A - Ventral view of a whole adult worm of $P$. medians, Os: Oral sucker, Gp: Genital pore, Vs: ventral sucker; B - Oral sucker and the tegument on the antero-ventral spinulate surface, Sp: Spines 


\section{Monogenea}

Family: Polystomatidae

Polystoma skrjabini Buchvarov, 1984

Prevalence, intensity and range: One of 17 hosts infected $(5.88 \%, 1,1)$.

Polystoma skrjabini is first time observed in the Urinary bladder of $H$. arborea by Buchvarov, 1984 in Bulgaria, Düşen \& Öz (2004) and Yıldırımhan et al. (2006) were reported this species from different localities in $(H$. arborea) from Turkey.

Geographic range: East Europe and the Middle East (Buchvarov, 1984; Düşen \& Öz, 2004).

Specimens deposited: PAU-HELM-5/2013 (1 slide)

\section{Digenea}

Family: Lecithodendriidae

Pleurogenoides medians (Olsson, 1876) Travassos, 1921

Prevalence, intensity and range: Hosts infected, One of 17 hosts infected $(5.88 \%, 7,7)$.
Other reported hosts: $P$. medians has been reported in various amphibians and reptiles species, Rana ridibunda (Satmann, 1990), Triturus cristatus (Shimalov et al., 2001), T. vulgaris (Vojtková \& Vojtek, 1975; Shimalov et al., 2001); Bombina bombina, (Vojtková \& Vojtek, 1975), Bo. variegata, (Vojtková \& Vojtek, 1975), Bufo bufo (Shimalov\& Shimalov, 2001), B. calamita, (Vojtková \& Vojtek, 1975), B. vulgaris (Yamaguti, 1958), B. viridis (Düşen et al., 2010; Düşen \& Oğuz, 2010), H. arborea (Vojtková \& Vojtek, 1975; Düşen \& Öz, 2004), H. savignyi (Yıldırımhan et al., 2012), Rana arvalis (Vojtková \& Vojtek, 1975), R. camerani (Yıldırımhan et al., 2006b; Düşen, 2007), R. dalmatina (Buchvarov, 1977; Düşen et al., 2009), R. esculenta (Vojtková \& Vojtek, 1975; Buchvarov, 1977; Kuc \& Sulgostowska, 1988b), $R$. macrocnemis (Yıldırımhan et al., 2006c; Düșen, 2007), $R$. arvalis (Vojtková \& Vojtek, 1975), $R$. temporaria (Vojtková \& Vojtek, 1975; Cedhagen, 1977), R. holtzi (Topçu, 2002), Lacerta trilineata (Yamaguti, 1963;
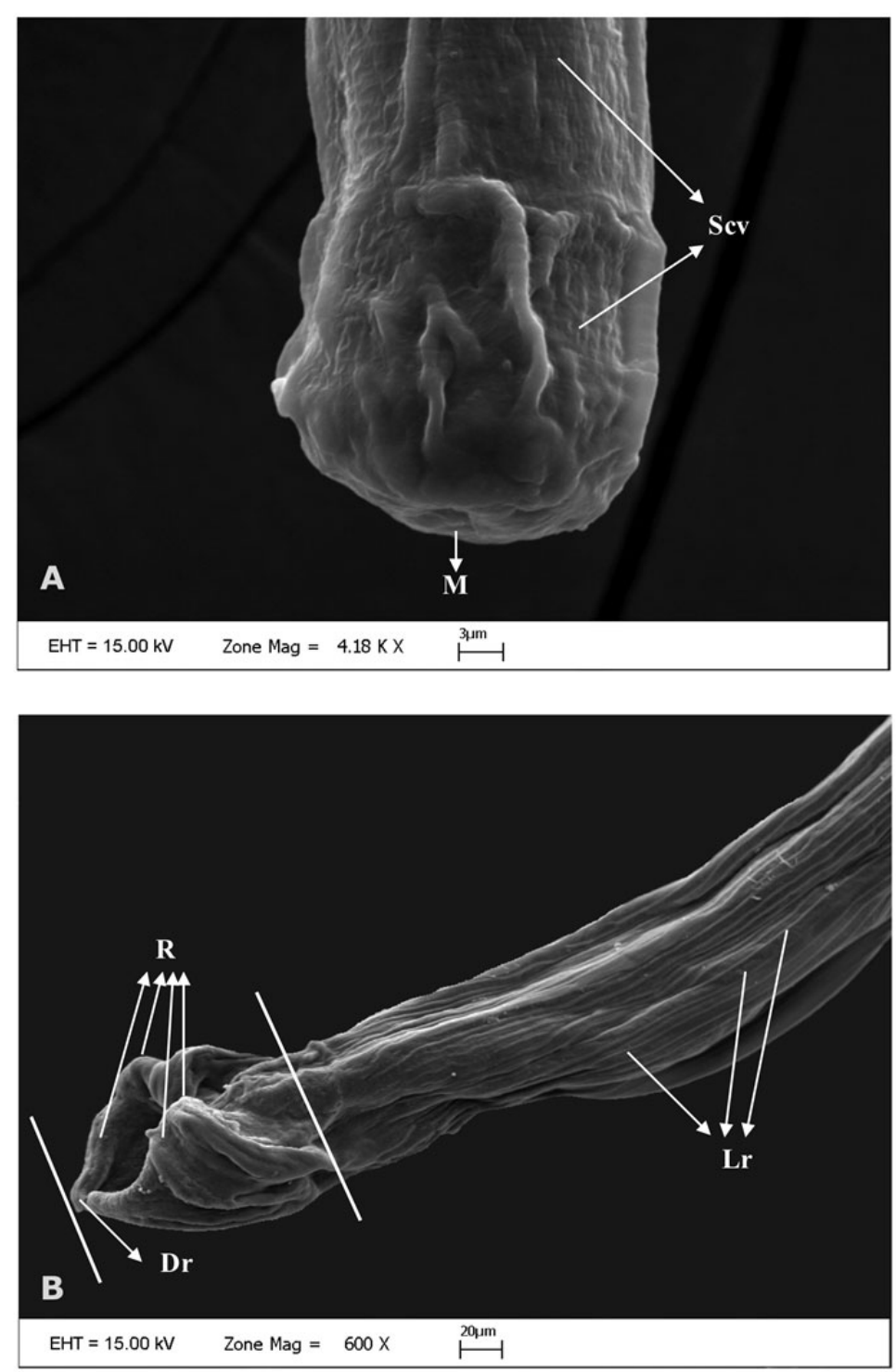

Fig. 3. SEM of specimens of Oswaldocruzia filiformis from $H$. orientalis

A - Cephalic end of male M: mouth and tegument, Scv: Simple cuticular vesicle; B - Caudal end of male, in lateral view of the caudal bursa (Between in two parallel white lines), Lr: longitudinal ridges; R: Rays; Dr: Dorsal ray 
Yildırımhan et al., 2011), L. agilis (Sharpilo et al., 2001); Natrix natrix (Kirin, 2002a) and Atheris hispida (Hassl, 2010; Hassl et al., 2010), Pelophylax ridibundus (Düşen \& Öz, 2013).

Geographic range: Europe and Asia (Yamaguti, 1958); Austrolasian Regions (Prudhoe \& Bray, 1982).

Specimens deposited: PAU-HELM-6/2013 (1 slide)

The tegument surface is covered with regularly arranged flattened hand like spines, the spines are more densely arranged towards the anterior end and more sparsely distributed towards the posterior end. The genital pore is also observed. The SEM images of this species is presented in Fig. 2.

\section{Nematoda}

Family: Molineidae

Oswaldocruzia filiformis (Goeze, 1782) Travassos, 1917

Prevalence, intensity and range: one of 17 hosts infected $(5.88 \%, 4,4)$.
Oswaldocruzia filiformis is recorded from various amphibian and reptile species, including $S$. salamandra (Buchvarov, 1977), T. alpestris and T. karelini (Buchvarov, 1977; Cedhagen 1988; Kirin \& Buchvarov, 2002), T. vulgaris (Buchvarov, 1977; Satmann, 1990; Shimalov et al., 2001), T. vittatus (Yıldırımhan, 2008), Bo. bombina and B. variegata (Buchvarov, 1977, Kirin \& Buchvarov, 2002), B. regularis (probably B. viridis) (Schad et al., 1960), B. viridis (Buchvarov, 1977; Yıldırımhan, 1999; Shimalov \& Shimalov, 2001; Düşen et al., 2010a; Düşen \& Oğuz, 2010), B. viridis (Buchvarov, 1977; Yıldırımhan, 1999; Shimalov \& Shimalov, 2001; Topçu \& Bayrak, 2000; Düşen et al., 2010a; Düşen \& Oğuz, 2010; Mohammad et al., 2010), B. bufo (Buchvarov, 1977; Yıldırımhan \& Karadeniz, 2007; Düşen \& Oğuz, 2010; Düşen, 2011); Pseudepidalea viridis (Düşen, 2011), Pelodytes caucasicus (Yıldırımhan et al., 2009), H. arborea (Buchvarov, 1977; Yıldırımhan et al., 2006a), R. camerani, R. dalmatina, (Buchvarov et al., 1975; Buchvarov, 1977; Kirin \& Buch-
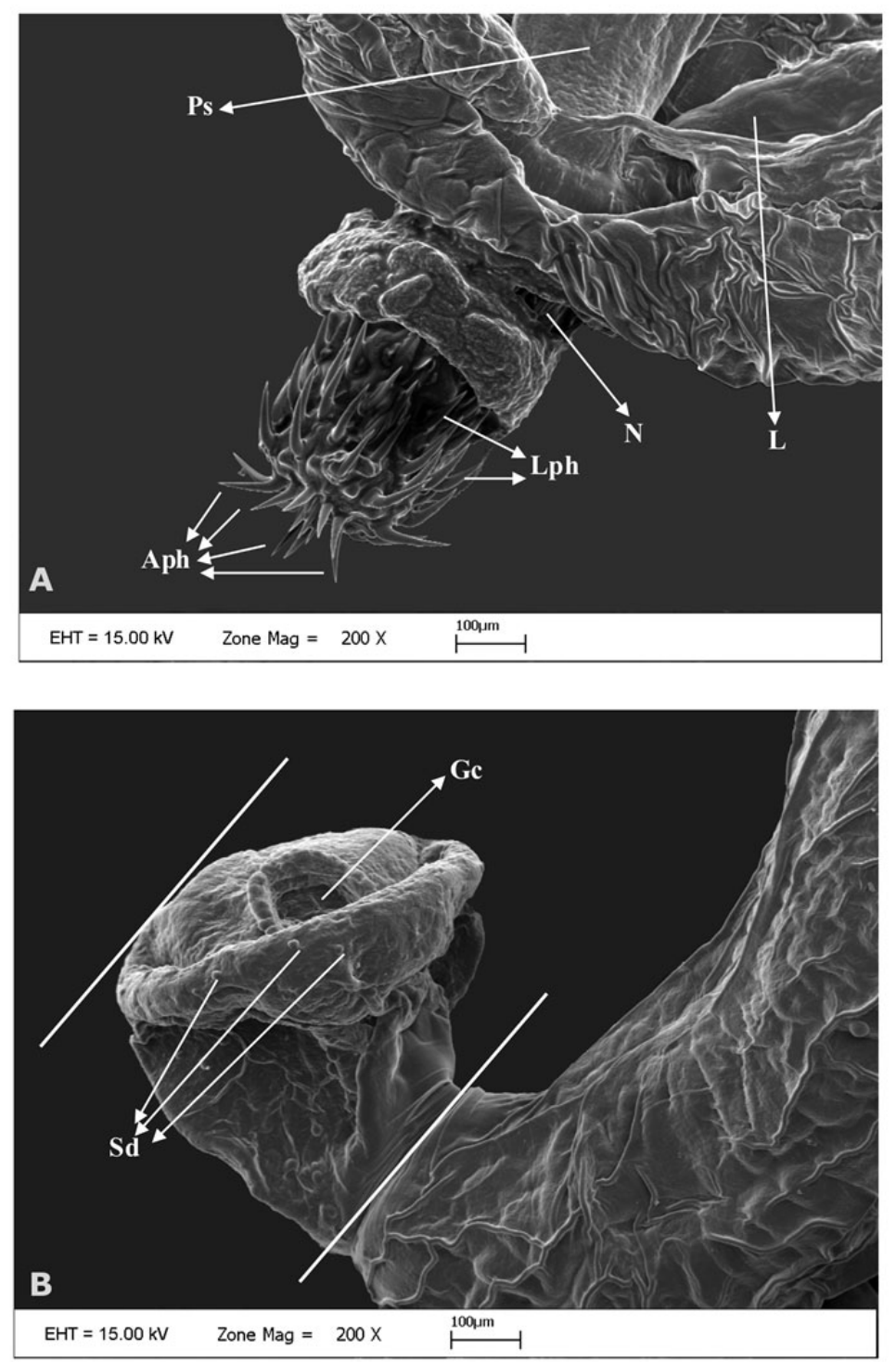

Fig. 4. SEM of pecimens of Acanthocephalus ranae (male) from $H$. orientalis 
varov, 2002; Düşen et al., 2009), R. kurtmuelleri (Hristovski et al., 2006), R. macrocnemis (Schad et al., 1960; Yildırımhan et al., 1997; Yıldırımhan et al., 2006c), $R$. ridibunda (Buchvarov, 1977; Yıldırımhan et al., 1996; Buchvarov et al., 1975; Kirin \& Buchvarov, 2002; Yıldırımhan et al., 2005a; Sağlam \& Arıkan 2006; Düşen \& Oğuz, 2010), R. temporaria, (Buchvarov, 1977; Cedhagen, 1988; Kirin \& Buchvarov, 2002), R. graeca (Božkov \& Stojkova, 1970; Buchvarov, 1977), Pe. ridibundus (Düşen \& Öz, 2013); Lacerta agilis, (Sharpilo et al., 2001; Shimalov et al., 2000; Mihalca et al., 2007), L. trilineata (Yıldırımhan et al.,2011), L. viridis (Biserkov \& Kostadinova, 1998; Kirin, 2002b; Borkovcová \& Kopřiva, 2005), L. vivipara (Shimalov et al., 2000); Anguis fragilis (Schad et al., 1960; Bertman \& Okulewicz, 1987; Shimalov et al., 2000; Borkovcová \& Kopřiva 2005; Düşen et al, 2010b), Zootoca vivipara (Sanchis et al., 2000), N. natrix (Bertman \& Okulewicz, 1987; Shimalov \& Shimalov, 2000; Kirin 2002b) and V. berus (Shimalov \& Shimalov, 2000).

Schad et al. (1960) were first time reported O. filiformis in Bufo regularis (probably this species is Pseudepidalea viridis in Turkey (formerly known as Bufo viridis)) and $R$. macrocnemis from Turkey. O. filiformis was observed in small intestines from $H$. orientalis samples in this study. Geographic range: Europe and Asia (Yamaguti, 1961). Specimens deposited: PAU-HELM-7/2013 (2 slides) The body has longitudinal ridges and these longitudinal ridges, some disappearing and others appearing near the caudal bursa, ridges not continuous along the nematode body. The SEM images of this species is presented in Fig. 3.

\section{Family: Cosmocercidae}

Cosmocerca ornata (Dujardin, 1845)

Prevalence, intensity and range: Two of 17 hosts were infected $(11.76 \%, 1,1-3)$.

There are several papers reporting Cosmocerca ornata from many species of amphibians and reptiles, including Bufo, Hyla, Rana, Triturus (Yamaguti, 1961), T. alpestris (Walton, 1933; Buchvarov, 1977; Shimalov et al., 2000), T. cristatus (Walton, 1933; Shimalov et al., 2001), T. vulgaris (Shimalov et al., 2001), Bo. bombina, (Buchvarov, 1977; Grabda-Kazubska \& Lewin, 1989), Bo. variegata (Buchvarov, 1977; Grabda-Kazubska \& Lewin, 1989; Satmann, 1990; Kirin \& Buchvarov, 2002), B. viridis (Buchvarov et al., 1975; Buchvarov, 1977; Vashetko \& Siddikov,1999; Masshaii, 2005; Düşen et al., 2010a, Düşen \& Oğuz, 2010), Pseudepidalea viridis (Düşen, 2011), B. bufo (Düşen, 2011), Pe. caucasicus (Yıldırımhan et al., 2009), H. arborea (Buchvarov, 1977, Yildırımhan et al., 2006a), Pelobates syriacus (Shimalov et al., 2000), $R$. esculenta (Walton, 1933; Buchvarov, 1977), R. arvalis (Cedhagen, 1988; Kuc \& Sulgostowska, 1988b), R. temporaria, (Walton, 1933; Buchvarov, 1977; Kuc \& Sulgostowska, 1988b), R. graeca (Božkov \& Stojkova, 1970; Buchvarov, 1977), R. holtzi (Yıldırımhan et al., 2006c), R. macrocnemis (Yıldırımhan et al., 2006c; Düşen,
2007), R. ridibunda (Buchvarov et al., 1975; Buchvarov, 1977; Kuc \& Sulgostowska, 1988a; Masshaii et al., 2000; Kirin \& Buchvarov, 2002; Kirin, 2003a, b; Yıldırımhan et al., 2005a; Düşen \& Öz, 2006; Düşen \& Oğuz, 2010; Düşen et al., 2010), R. camerani (Yıldırımhan et al., 2006b; Düşen, 2007), R. tavasensis (Düşen, 2012), Chiasmocleis capixaba (Van Sluys et al,. 2006) and A. fragilis (Shimalov et al., 2000; Düşen et al., 2010b).

Schad et al. (1960) were first time recorded C. ornata in Pseudepidalea viridis (formerly known as Bufo viridis), $R$. macrocnemis and $R$. ridibunda in Turkey. In this study, $C$. ornata was observed in small and large intestines of $H$. orientalis specimens.

Geographic range: New and Old Worlds (Baker, 1987).

Specimens deposited: PAU-HELM-8/2013 (2 slides)

Family: Physalopteridae

Abbreviata sp. (larvae - Encapsulated larvae in submucosa of stomach and small intestine).

Prevalence, intensity and range: Hosts infected, 2 of 17 hosts (11.76\%, Uncountable).

Other reported hosts: Fernando (1989) observed this nematode larvae in $R$. ridibunda from Saudi Arabia; Fernando (1989) reported that parasite larvae in brown cysts where located subcutaneously on body wall, heavy infestations also occured in the submucosae of stomach, small intestine and mesenteries and embedded deeply in them muscle. Düşen and Öz (2006) observed this encapsulated larvae in submucosa of stomach and small intestines of $R$. ridibunda from Southwest of Turkey (in Antalya region); Düşen and Öz (2013) also reported Pe. ridibundus from Innerwest part of Turkey (in Denizli province); Borkovcová and Kopřiva (2005) recorded this nematode species in some lizards (A. fragilis, L. viridis and L. agilis) and one snake (Coronella austriaca) species in South Moravia (Czech Republic). In this investigation, the larvae of Abbreviata sp. were observed numerous, and deeply embedded in submucosa of the stomach and small intestine in $H$. orientalis, therefore counting was difficult.

Geographic range: Europe Asia, and Western Australia (Anderson, 2000).

Specimens deposited: PAU-HELM-9/2013 (1 slide)

Acanthocephala

Family: Echinorhynchidae

Acanthocephalus ranae (Schrank, 1788) Lühe, 1911

Prevalence, intensity and range: Two of 17 hosts were infected $(11.76 \%, 2,2)$.

Other reported hosts: Rana sp., Bombinator sp., Hyla sp., Triturus sp., Salamandra sp., Diemictylus viridescens (Yamaguti, 1963), Bo. bombina (Buchvarov, 1977; Grabda-Kazubska \& Lewin, 1989; Y1ldırımhan et al., 2001a); B. variegata (Grabda-Kazubska \& Lewin, 1989); B. viridis (Buchvarov, 1977; Yıldırımhan, 1999; Vashetko \& Siddikov, 1999; Shimalov \& Shimalov, 2001); B. calamita (Shimalov \& Shimalov, 2001); B. bufo (Düşen, 2011), H. arborea (Düşen \& Öz, 2004), $R$. arvalis, $R$. dalmatina (Buchvarov, 1977; Düşen et al, 2009); R. temporaria 
Table 1. Prevalence, Mean intensity, infection sites and range of helminths in H. orientalis

\begin{tabular}{|c|c|c|c|c|c|}
\hline HELMINTH GROUP & $\begin{array}{l}\text { Developmental } \\
\text { stage }\end{array}$ & $\begin{array}{c}\text { Site } \\
\text { of infection }\end{array}$ & $\begin{array}{c}\text { No. of infected } \\
(\%)\end{array}$ & $\begin{array}{c}\text { Mean } \\
\text { intensity }\end{array}$ & Range \\
\hline \multicolumn{6}{|l|}{ Monogenea } \\
\hline Polystoma skrjabini Batcharov, 1984 & Adult & UB & $1(5.88)$ & 1 & 1 \\
\hline Digenea & & & & & \\
\hline $\begin{array}{l}\text { Pleurogenoides medians } \\
\text { (Olsson, 1876) Travassos, } 1921\end{array}$ & Adult & SI & $1(5.88)$ & 7 & 7 \\
\hline Nematoda & & & & & \\
\hline $\begin{array}{l}\text { Oswaldocruzia filiformis (Goeze, 1782) } \\
\text { Travassos, } 1917\end{array}$ & Adult & SI & $1(5.88)$ & 4 & 4 \\
\hline $\begin{array}{l}\text { Cosmocerca ornata (Dujardin, 1845) } \\
\text { Abbreviata } \mathrm{sp.}\end{array}$ & Adult & $\begin{array}{l}\text { LI, SI } \\
\text { ST, SI }\end{array}$ & $2(11.76)$ & 1 & $1-3$ \\
\hline $\begin{array}{l}\text { (Encapsulated larvae in submucosa of } \\
\text { stomach and small intestine) }\end{array}$ & Larvae & & $2(11.76)$ & - & Uncount. \\
\hline $\begin{array}{l}\text { Acanthocephala } \\
\text { Acanthocephalus ranae } \\
\text { (Schrank, 1788) Lühe, } 1911\end{array}$ & Adult & SI & $2(11.76)$ & 1 & 2 \\
\hline
\end{tabular}

(Buchvarov, 1977; Cedhagen, 1988; Kuc \& Sulgostowska, 1988b); R. esculenta (Buchvarov, 1977; Kuc \& Sulgostowska, 1988b); R. macrocnemis (Yildırımhan et al., 1997; Yıldırımhan et al., 2006c; Düşen, 2007); R. camerani (Yildırımhan et al., 2006b), R. kurtmuelleri (Hristovski et al., 2006); R. tavasensis (Düşen, 2012), Pe. ridibundus (Düşen \& Öz, 2013); Mertensiella caucasica (Yıldırımhan et al., 2001b; 2005b); A. fragilis (Shimalov et al., 2000). N. natrix (Yamaguti, 1963; Shimalov \& Shimalov, 2000). Dimitrova et al. (2008) were reported in mammal species (Eurasian otter, Lutra lutra) as a paratenic host.

Also, A. ranae is reported in H. arborea from Turkey by Düşen \& Öz (2004).

Geographic range: Europe, U.S.A., Russia (Yamaguti, 1963); Turkey (Oğuz et al., 1994).

Specimens deposited: ZDEU HEL-10/2013 (1 slide)

The neck is wide. Apical hooks were observed as acutely curved compared to other proboscis hooks. The sensory discs and genital canal were also observed the inside of bursa. The SEM images of this species is presented in Fig. 4.

Six helminth species were found infecting $H$ orientalis in this investigation. The site of infection in the frogs and the data on infection parameters for each hosts, are shown in Table 1. In summary, 20 individuals of 6 helminth species were collected from the $17 \mathrm{H}$. orientalis examined. Monogenea was observed in Urinary bladder, Digenans was observed in small intestines, Nematodes were observed in large-small intestines, and cysts on the surface of the intestinal wall; Acanthocephala was also observed in small intestine of this species. According the data obtained 8 $(47.06 \%) H$. orientalis harbored the one or more species of helminths and the remaining $7(41.18 \%)$ were uninfected. There were $1.12 \pm 0.35(1-2)$ helminth species per infected host and there were $3.33 \pm 2.42(1-7)$ helminth 42 individuals per infected host (the total number of larvae of Abbreviata sp. is not included this calculation, because counting was difficult).

The helminths that were observed $H$. orientalis are generally common parasites of European anurans, except Polystoma skrjabini (Yamaguthi, 1961; 1963; Buchvarov, 1977; Anderson, 2000; Yıldırımhan, 1999; Yıldırımhan et al., 2007, Düşen \& Öz, 2006, Düşen et al., 2010a; Düşen and Öz, 2013), and first time reported for $H$. orientalis from Turkey.

\section{Acknowledgements}

This study is supported by the Pamukkale University Scientific Research Projects Unit Project number: 2008BSP005. We also thank, for permission and helps, the Department of National Parks and Wildlife of the Republic of Turkey Ministry of Forestry and Water Affairs.

\section{References}

Anderson, R. C. (2000): Nematode Parasites of Vertebrates: Their Development and Transmission. (2nd Edition), CABI Publishing, Wallingford, Oxon, U.K., 650 pp. DOI: 10.1079/9780851994215.0000

BAKER, M. R. (1987): Synopsis of the Nematoda parasitic in amphibians and reptiles. Memorial University of Newfoundland, Occas. Pap. in Biol., 1: 1 - 325

Baran, I., Ilgaz, Ç., Avci, A.,Kumlutaș, Y., Olgun, K. 2012. Türkiye Amfibi ve Sürüngenleri. TÜBİTAK (The Scientific and Technological Research Council of Turkey) Press, 204 pp. (In Turkish)

Bertman, M., OKUlewiCZ, A. (1987): Lizards (Anguis fragilis L.) and snakes (Natrix natrix (L.)) as new hosts of Oswaldocruzia filiformis (Goeze, 1782) Travassos 1917 
(Nematoda). Wiadomosci Parazytol., 33(2): 209 - 212 (In Polish)

Biserkov, V., Kostadinova, A. (1998): Intestinal helminth communities in the green lizard, Lacerta viridis, from Bulgaria. J. Helminthol., 72(3): 267 - 271. DOI: $10.1017 /$ S0022149X00016540

Borkovcová, M., KoPŘIVA, J. (2005): Parasitic helminths of reptiles (Reptilia) South Moravia (Czech Republic). Parasitol. Res., 96: 77 - 78. DOI: 10.1007/s00436-004-1258-6 BožKov, D., Stojkova, R. (1970): Beitrag zur untersuchung der Helminthenfauna der Rana graeca in Bulgarien. Bulletin de L'institute de Zoologie et Musée, Academie Bulgare des Sciences, 69 - 75. (In Bulgarian)

Buchvarov, G. K., Petrov, P., Chochev, B. (1975): To the question about helminthofauna of Amphibious Eucaudate (Amphibia-Eucaudata) of Velingrad's District. Universite de "P Hilendarski", Travaux Scientifiques, Biologie 13 (4): $53-64$

Buchvarov, G. K. (1977): Catalogue des helminthes des Amphibies en Bulgarie. Universite de Plovdiv "P Hilendarski”, Plovdiv, Bulgaria, 53 pp. (In Bulgarian)

Buchvarov, G. K. (1984): Polystoma skrjabini n. sp. (Polystomatidae Gambl, 1896) a parasite on Hyla arborea (Linnaeus, 1758), in Bulgaria. Comptes Rendus de l' Acadēmie Bulgare des Sciences. Tome 37, No: 5: 697-699. Cedhagen, T. (1988): Endoparasites in some Swedish amphibians. Acta Parasitol., 33: $107-113$

Dimitrova, Z. M., TzvetKov, Y. Todev, I. (2008): Occurrence of acanthocephalans in the Eurasian otter Lutra lutra (L.) (Carnivora, Mustelidae) in Bulgaria, with a survey of acanthocephalans recorded from this host species. Helminthologia. 45(1): 41 - 47. DOI: 10.2478/s11687008-0007-2

DüŞEN, S., Öz, M. (2004): Helminth Parasites of the Tree Frog, Hyla arborea (Linnaeus, 1758) (Anura: Hylidae) from Southwest Turkey. Comp. Parasitol. 71(2): 258 261. DOI: $10.1654 / 4123$

DÜŞEN S., ÖZ, M. (2006): Parasitic helminths of the marsh frog, Rana ridibunda Pallas, 1771 (Anura: Ranidae), from Antalya Province, south-west Turkey. Comp. Parasitol., 73(1): 121-129. DOI: 10.1654/4162.1

DÜŞEN, S. (2007): Helminths of the two mountain frogs, Banded frog, Rana camerani Boulenger, 1886 and Uludağ Frog Rana macrocnemis Boulenger, 1885 (Anura: Ranidae), collected from Antalya Province. Acta Parasitol. Tur., 31(1): $84-88$

DÜŞEn, S., UĞURTAş, İ. H., AydoĞdu, A., OĞUZ, M. C. (2009): The helminth community of the Agile frog, Rana dalmatina Bonaparte, 1839 (Anura: Ranidae) Collected from Nortwest of Turkey. Helminthologia, 46(3): 177 182. DOI: $10.2478 / \mathrm{s} 11687-009-0033-8$

DÜŞEN, S., OĞUZ, M. C. (2010): Metazoan endoparasites of three species of anurans collected from the Middle Black Sea region of Turkey. Helminthologia, 47(4): 226 - 232. DOI: 10.2478/s11687-010-0035-6

Düşen, S., OĞUz, M. C., Barton, D., P. Aral, A., ŞuleKoĞLU, S., TePE, Y. (2010A): A metazoan parasitological research of three species of Anurans collected from the Çanakkale Province, Northwestern Turkey. North-West J. Zool., 6(1): 25 - 35

Düşen, S., UĞURTAŞ, İ. H., AYdoĞDU, A. (2010B): Nematode parasites of the two limbless lizards: Turkish worm lizard, Blanus strauchi (Bedriaga, 1884) (Squamata: Amphisbaenidae), and slow worm, Anguis fragilis Linnaeus 1758 (Squamata: Anguidae), from Turkey. Helminthologia, 47(3): 158 - 163. DOI: 10.2478/s11687-010-0024-9

DÜSsEN S. (2011): The helminth parasites of the bufonid toads, European Common Toad, Bufo bufo (Linnaeus, 1758) and European Green toad, Bufo (Pseudepidalea) viridis Laurenti, 1768 (Anura: Bufonidae), collected from Denizli Province, Inner-West Anatolia Region, Turkey. Helminthologia. 48(2): 101 - 107. DOI: 10.2478/s11687011-0019-1

DÜŞEN, S. (2012): First data on helminthfauna of the locally distributed a mountain frog, "Tavas Frog", Rana tavasensis Baran and Atatür, 1986 (Anura: Ranidae), from Inner-West Anatolia Region, Turkey. Turkish Journal of Zoology, 36(4): 496 - 502. DOI: 10.3906/zoo-0909-15

DÜŞEN, S., ÖZ, M. (2013): Helminth fauna of the Eurasian marsh frog, Pelophylax ridibundus (Pallas, 1771) (Anura: Ranidae), collected from Denizli Province, Inner-West Anatolia Region, Turkey. Helminthologia. 50(1): 57 - 66. DOI: $10.2478 / \mathrm{s} 11687-013-0108-4$

FERnANDO, M. M. (1989): The parasitic burden of the frog Rana ridibunda Pallas, 1771 from Saudia Arabia. A preliminary list of parasitic helminths. Herpetol. J., 1: $415-$ 417

GÜL, S.,KuTRuP, B. ÖZdEMIR, N. (2012): Patterns of distribution of tree frogs in Turkey based on molecular data. Amphibia - Reptilia, 33: 95 - 103. DOI: 10.1163/156853 812X624432

GRABDA-KAZUBSKA, B., LEwIN, J. (1989): The helminth fauna of Bombina bombina (L.) and Bombina variegata (L.) in Poland. Acta Parasitol., 34: 273 - 279

GVožDík, V. (2010): Second species of tree frog, Hyla orientalis (formerly $H$. arborea), from Iran confirmed by acoustic data. Herpetology Notes, 3: $41-44$

Gvoždík V., Moravec J., Klutsch, C., Kotlík, P. (2010): Phylogeography of the Middle Eastern tree frogs (Hyla, Hylidae, Amphibia) as inferred from nuclear and mitochondrial DNA variation, with a description of a new species. Mol. Phylogenet. Evol., 55: 1146 - 1166. DOI: 10.1016/j.ympev.2010.03.015

HASSL, A. R (2010): A case of a facultative life-cycle diversification in the fluke Pleurogenoides sp. (Lecithodendriidae, Plagiorchiida). Wien Klin. Wochenschr. Suppl. 3: 91 - 93. DOI: 10.1007/s00508-010-1444-8

Hassl, A. R., Richter, B., KüBberheiss, A. (2010): Captive snake's care as parasite's life cycle conservation program. Herpetozoa, 23(1/2): $83-85$

Hristovski, N., Smilkov, S., Tomovska, D., Popovich E., Kostich, D. (2006): Helmintofauna of Rana kurtmuelleri Gayda, 1940 syn. Rana balcanica Shneider et Sinish, 1992 (Anura:Ranidae) from Dojran Lake, Makedonia and Greece. In Abstracts of $10^{\text {th }}$ International Congress on the Zoogeography and Ecology of Greece and 
Adjacent Regions Patras, Greece. June 26-30.

KIRIN, D. (2002a): New records of the helminth fauna from grass snake, Natrix natrix L., 1758 and dice snake, Natrix tessellata Laurenti, 1768 (Colubridae: Reptilia) in South Bulgaria. Acta Zool. Bul., 54: 49 - 53

KIRIN, D. (2002b): New data on the helminth fauna of Lacerta viridis Laurenti, 1768, and Podarcis muralis (Laurenti, 1768) (Reptilia: Lacertidae) in Bulgaria. Acta Zool. Bulg., 54(1): $43-48$

KIRIN, D. (2003a): Biodiversity and ecological particulars of the helminth communities in Rana ridibunda Pallas, 1771, from districts of town Saedinenie. Exp. Pathol. Parasitol., 6 (11): $31-36$

KIRIN, D. (2003b): Biological diversity and ecological measurements of the helminth communities of Rana ridibunda from District of Town Vidin. Exp. Pathol. Parasitol., 6(11): $37-43$

Kirin, D., BuchVarov, G. (2002): Biodiversity of of the helminth communities of acaudated Amphibians (Amphibia: Ecaudata) from Bistritsa Riverside (Gotse Delchev Region). Exp. Pathol. Parasitol., 5(8): 13 - 16

KuC, I., SulgostowsKa, T. (1988a): Helminth fauna of Rana ridibunda Pallas, 1771 from Goclawski Canal in Warszaw (Poland). Acta Parasitol., 33: 101 - 105

KuC, I., SulgostowsKa, T. (1988B): Helminth fauna of frogs in the forest of Kampinos near Warszawa. Acta Parasitol., 33: $267-272$

MasshaiI, N., BAlOUCH, M., Mobedi, I. (2000): New records about helminth parasites of the marsh frog, Rana ridibunda (Anura: Ranidae), from the North of Iran. Iran. J. Fish. Sci., 2: $77-88$

MASHAII, N. (2005): Helminth Parasites of green toad, Bufo viridis (Anura: Bufonidae), Tree frog, Hyla arborea savignyi (Anura: Hylidae) and Marsh Frog, Rana ridibunda ridibunda (Anura: Ranidae) from Southwest of Iran. Iran. J. Vet. Res., 6(3): $67-73$

Mohammad, M. K., Al-Moussawi, A. A., Jasim, S. Y. (2010): Helminth Parasites of the Green Toad Bufo viridis Laurenti, 1768 in Baghdad Area, Central Iraq. Egypt. Acad. J. biolog. Sci., 2(1): 17 - 25. ISSN: 2090-0759

Mihalca, A. D., Gherman, C., Ghira, I., Cozma, V. (2007): Helminth parasites of reptiles (Reptilia) in Romania. Parasitol. Res., 95: 77 - 78. DOI: 10.1007/s00436007-0486-y

OĞUZ, M. C., Altunel, F. N., UĞURTAŞ, İ. H. (1994): An investigation of the species of Plathelminthes and Acanthocephalus ranae (Schrank, 1788, Acanthocephala) of marsh frogs (Rana ridibunda Pallas, 1771) which were collected from the Bursa and Edirne Regions. Turk J. Zool., 18: 47 - 51 (In Turkish, with English abstract)

Prudhoe S., Bray S. A. (1982): Platyhelminth Parasites of Amphibia. British Museum of Natural History. Oxford University Press., 217 pp.

SAĞLAM, N., ARIKAN, H. (2006): Endohelminth parasites of the Marsh Frog Rana ridibunda from Hazar Lake, Turkey. Dis. Aquat. Org., 72: 253 - 260. DOI: 10.3354/dao072253

SANChis, V., Roig, J. M., CARretero, M. A., RocA, V.,
Llorente, G. A. (2000): Host-parasite relationships of Zootoca vivipara (Sauria: Lacertidae), in Pyreenes, North Spain. Folia Parasitol., 47: 118 - 122

SATTMANN. H. (1990): Endohelminths of some amphibians from Northern Greece (Trematoda, Acanthocephala, Nematoda; Amphibia: Triturus, Rana, Bombina). Herpetozoa 3(1/2): $67-71$

Schad, G. A., Kuntz, R. E., Wells, W. H. (1960): Nematode parasites from Turkish vertebrates: An annotated list. Can. J. Zool., 38: 949 - 963. DOI: 10.1139/z60-101

SchATTEN, H. JAMES, P. (2008): Biological Low-Voltage Scanning Electron Microscopy Springer New York, NY, USA 318 pp. DOI: 10.1007/978-0-387-72972-5

Sharpilo V. P., Biserkov, V., Kostadinova, A., BeHnKe, J. M., KuzMIN, Y. I. (2001): Helminths of the sand lizard, Lacerta agilis (Reptilia, Lacertidae), in the Palaearctic: faunal diversity and spatial patterns of variation in the composition and structure of component communities. Parasitology, 123: 389 - 400. DOI: 10.1017/ S0031182001008587

Shimalov, V. V., Shimalov, V. T. (2000): Helminth fauna of snakes (Reptilia, Serpentes) in Belorussian Polesye. Parasitol. Res., 86: 340 - 341. DOI: 10.1007/s004 360050055

Shimalov, V. T., Shimalov, V. V., Shimalov, A. V. (2000): Helminth fauna of lizards in the southern part of Belarus. Parasitol. Res., 86: 343. DOI: 10.1007/s004360 050057

Shimalov, V. V., Shimalov V. T. (2001): Helminth fauna of toads in Belorussian Polesie. Parasitol. Res., 87: 84. DOI: $10.1007 / \mathrm{s} 004360000266$

Shimalov, V. V., Shimalov, V. T., Shimalov, A. V. (2001): Helminth fauna of newts in Belarusian Polesie. Parasitol. Res., 87: 356. DOI: 10.1007/PL00008592

StÖCK, M., DubEY, S., KLÜTSCH, C., LiTVINCHUK, S.N., SCHEIDT, U., PERRIN, N. (2008): Mitochondrial and nuclear phylogeny of circum-Mediterranean tree frogs from the Hyla arborea group. Mol. Phylogenet. Evol. 49: 1019 1024. DOI: 10.1016/j.ympev.2008.08.029

TopçU, A. (2002): The digestive system helminths found in the Taurus frog (Rana holtzi Werner, 1898), In abstracts of XVI th National Biology Congress, (Toros Kurbağasının, Rana holtzi Werner, 1898 Sindirim Sisteminde Bulunan Helmintler, XVI. Ulusal Biyoloji Kongresi), 04-07 Eylül 2002 Malatya. (In Turkish)

TOPÇU, A., BAYRAK, N. (2000): The digestive system helminths of the Rana ridibunda 1771, Pallas and Bufo (Pseudepidalea) viridis Laurenti, 1768 (Anura) distributed in Nigde Province and its vicinity. In abstracts of $X V$ th National Biology Congress, (Niğde İli ve Çevresindeki Anura Türlerinin (Rana ridibunda 1771, Pallas ve Bufo (Pseudepidalea) viridis Laurenti, 1768) Sindirim Sisteminde Bulunan Helmintler, $X V$. Ulusal Biyoloji Kongresi, 5 - 9 Eylül 2000 Ankara. (In Turkish)

VAn Sluys, M., Schittini, G., Marra, R. V., AzeVedo, A., ViCENTE J. J., VRCIBRADIC, D. (2006): Body size, diet and endoparasites of the microhylid frog Chiasmocleis capixaba in an Atlantic Forest Area of Southern Ba- 
hiastate, Brazil. Brazil. J. Biol., 66(1A): 167 - 173. DOI: 10.1590/S1519-69842006000100021

VASHETKO, E. V., SidDiKOV, B. H. (1999): The effect of the ecology of toads on the distribution of helminths. Turk. J. Zool., 23: $107-110$

VojtKova, L., VojteK, J. (1975): Die Trematoden der Amphibian inder Tschechowakei (Motolice Obojzivelniki CSSR) II Larval stadian (Mesocercariana und metacercarien) Folia Biologia, Tomus 15, Opus 2, pp 86.

Walton, A. C. (1933): The nematoda as parasites of Amphibia. J. Parasitol. 20: (1) 1 - 33

YAMAGUTI, S. (1958): Systema Helminthum. Vol. I: The Digenetic Trematodes of Vertebrates. Interscience Publishers, New York\& London 1575 pp.

YAmAGuTI, S. (1961): Systema Helminthum: The nematodes of vertebrates. Vol III., Part II. Nematodes of Amphibians. Intersciences Publishers Ltd. London, England 679 pp.

Yamaguti, S. (1963): Systema Helminthum. Acanthocephala. Vol. V. Intersciences Publishers, London, England. 423 pp.

Yildirimhan, H. S., UĞurtaş, İ. H., Altunel, F. N. (1996): An investigation on helminths of Rana ridibunda Pallas, 1771 (marsh frog). Acta Parasitol. Tur., 20: 113 130 (In Turkish, with English abstract)

Yildirimhan, H. S., UĞUrtaş I. H., Altunel, F. N. (1997): An investigation on parasitic helminths of Rana macrocnemis Boulenger, 1885 (Uludag frog). Turk. J. Zool. 21: $467-473$

YILDIRIMHAN, H. S. (1999): Researches on parasitic helminths of Bufo viridis Laurenti, 1768 (Anura: Amphibia). Turk. J. Zool, 23: $177-195$

Yildirimhan, H. S., AYdoĞdu, A., UĞURTAŞ, I. H., Altunel, F. N. (2001a): Helminth fauna of Bombina bombina (Linnaeus, 1767) (Fire-Bellied Toad) collected from Sakarya and Edirne (Turkey). Acta Parasitol. Tur., 25(3): 308 - 311 (in Turkish, with English abstract)

Yildirimhan, H. S., AYdoĞdu, A., UĞURTAŞ, I. H., Altunel, F. N. (2001b): An investigation on Plathelminth and Acanthocephala of Mertensiella caucasica (Caucasian Salamander). Acta Parasitol. Tur., 25: 393 - 397 (In Turkish, with English abstract)

YildirimHAN, H. S., KARAdENIZ, E., GÜRKAN, E., KOYUn,
M. (2005a): Metazoon parasites of the Marsh frog (Rana ridibunda Pallas, 1771; Anura) collected from the different regions in Turkey. Acta Parasitol. Tur., 29 (2): 135 - 139 (In Turkish with English abstract)

Yildirimhan, H. S., Bursey C. R., GoldberG, S. R. (2005b): Helminth parasites of the Caucasian salamander, Mertensiella caucasica, from Turkey. Comp. Parasitol., 72(1): 75 - 87. DOI: 10.1654/4152

Yildirimhan, H. S., Altunel, F. N., UĞURTaş, İ. H. (2006a): Helminth Parasites of Hyla arborea (Linneaus, 1758) (Tree Frog) Collected from Bursa, Edirne and Sakarya. Acta Parasitologica Turcica (Türkiye Parazitoloji Dergisi), 30(1): 56 - 59 (In Turkish with English abstract) Yildirimhan, H. S., GoldberG S. R., Bursey, C. R. (2006b): Helminth parasites of the Banded Frog, Rana camerani (Ranidae) from Turkey. Comp. Parasitol., 73(2): 222 - 236. DOI: 10.1654/4229.1

Yildirimhan, H. S., Bursey, C. R. GoldberG, S. R. (2006c): Helminth parasites of theTaurus frog, Rana holtzi, and the Uludag frog, Rana macrocnemis, with remarks on the helminth community of Turkish anurans. Comp. Parasitol., 73(2): 237 - 248. DOI: 10.1654/4191.1

YILDIRIMHAN, H. S., KARADENIZ, E. (2007): Helminth Parasites of the Common Toad, Bufo bufo (Linnaeus, 1758) (Anura: Bufonidae) from Northeast Turkey. Comp. Parasitol., 74(1): 176 - 178. DOI: 10.1654/4246.1

YILDIRIMHAN, H. S. (2008): A Preliminary investigation on helminth fauna of Triturus vittatus (Jenyns, 1835) and $T$. karelinii (Strauch, 1870). Acta Parasitol. Tur., 32(2): $158-$ 160 (In Turkish with English abstract)

YILDIRIMHAN, H. S., BURSEY, C. R. GOLDBERG, S. R. (2009): Helminth Parasites of the Caucasian Parsley Frog, Pelodytes caucasicus, from Turkey. Comp. Parasitol., 76(2): 247 - 257. DOI: 10.1654/4376.1

Yildirimhan, H. S., Bursey, C. R., Altunel, F. N. (2011): Helminth parasites of the Balkan green lizard, Lacerta trilineata Bedriaga 1886, from Bursa, Turkey. Turk. J. Zool., 35(4): 519 - 535. DOI: 10.3906/zoo-0910-1 YILDIRIMHAN, H. S., NURHAN, S., İNCEDOĞAN, S., BURSEY, C. R. (2012): Helminth parasites of the lemon-yellow tree Anura and Urodela, Hyla savignyi (Hylidae), from Turkey. Turk. J. Zool., 36: 171 - 184. DOI: 10.3906/zoo-1006-9 